\title{
Marketing Effectiveness: Metrics for Effective Strategic Marketing
}

\author{
Frantisek Milichovsky, Iveta Simberova
}

\author{
Brno University of Technology \\ Kolejni 2906/4, 61200 Brno, Czech Republic \\ E-mail.milichovsky@fbm.vutbr.cz,simberova@fbm.vutbr.cz \\ cross $^{\text {ref }}$ http://dx.doi.org/10.5755/j01.ee.26.2.3826
}

\begin{abstract}
The topic of marketing effectiveness is considered to be a very up-to-date subject in the highly competitive environment. Marketing effectiveness may be characterized as the function of improving the process where marketers go to market with the goal of optimizing their own marketing resources spent to achieve even better results for both of the short- and longterm strategic marketing objectives. Not only the improved visibility into marketing effectiveness has helped companies to better prioritize their efforts, but it also has improved the quality and precision of the marketing resources demanded by the sales force. Finding the appropriate key metrics should contribute to the evaluation of marketing effectiveness. Strategic marketing is included in strategic management, which helps to improve the company's market share. However, there is an increasing trend of creation effectiveness in companies and it is necessary to check returns of finance and search for efficiency of the funds put into marketing. Performance management can be defined as a system utilizing the information to introduce appropriate changes in the organizational culture, systems and processes to achieve optimal performance agreement targets, and the allocation of resource and information management on possible modifications of business strategy. The scientific objective of the paper is to look for the set of metrics, which is important from the marketing strategic point of view, and includes the specific performance group. Data from primary research was used. The entire primary research focused on the evaluation of enterprises in the area of business and marketing activities (and their performance) in the Czech Republic due a questionnaire survey.
\end{abstract}

Keywords: Marketing efficiency, marketing metrics, effectiveness, performance, strategy marketing.

\section{Introduction}

Pressures on competitiveness from global sources and the additional problems imposed by a slow economic growth, add urgency to the imperative for searching out greater effectiveness and superior performance of a company. The corporate environment has become more difficult than in the past. It is important to have all strategic activities more interactive to increase their own comprehensiveness (Neil et al., 2007). Planning the strategic marketing as a part of corporate complexity takes similar approaches to defining a strategic plan for the whole business unit (Kocmanova \& Simberova, 2012).

(Gok \& Hacioglu, 2010, p. 296-297) note very precisely in their paper that corporate financial goals of marketing have broadened to include those who invest in, benefit from, and take responsibility for performance. Thus, the challenge of the marketing function is to document how individual marketing activities could be comprehensively measured in condition of their contribution to the company's financial performance (Sheth \& Sisodia, 2002; Rust et al., 2004; Gok \& Hacioglu, 2010, p. 296).

On the other hand, these corporate activities are specific by the complexity of all marketing activities, compounded by limited and poor-quality data related to the marketing efforts in company financial statements (Kahn \& Myers, 2005; Gok \& Hacioglu, 2010, p. 296).

In many industries, increasing financial pressures have led to focusing on short-term measures, which has influenced future performance and has forced reductions in marketing expenses. At the same time, defined marketing expenditures are mainly long-term market investments with a financial return, top management has generally seen short-term costs with no documentable financial effect (Rust et al., 2004; Gronholdt \& Martensen, 2006; Gok \& Hacioglu, 2010, p. 296). Consequently, the marketing function has been of decreasing interest to top management and has received commensurately decreasing budgetary support. If the return on marketing investment could be documented, the role of marketing would be significantly elevated throughout the organization. Barring such documentation, marketing will continue to be marginalized (Lehmann, 2004; Webster et al., 2005; Baker \& Holt, 2004; Gok \& Hacioglu, 2010, p. 297), and marketers will become mere tacticians carrying out specific activities than persons in other fields have planned (Stewart, 2009; Gok \& Hacioglu, 2010, p. 296).

The definition of strategic management is an excessively general and large tool which needs to be separated to individual and more operative parts. All activities are closely connected together. Strategic management should be divided into (Doyle, 2008):

- Marketing strategy;

- Participation strategy;

- Operations strategy;

- Global strategy;

- Organizational strategy.

Strategic marketing (as a part of strategic management) processes information about the market and competitors and provides top management with background for strategic decisions. Strategic marketing is one of the development 
stages of marketing. (Tikkanen et al., 2007) define strategic marketing as a systematic approach which leads to increasing the management liability for adopted decisions, needing the localization of the organization in the market. The basic assumption consists in ensuring the increasing success without any surprise.

Strategic marketing is a part of company's strategy, which should be defined in different ways. (Jakubikova, 2008) gives three different views: (a) Strategic marketing is focused on planning future activities to define potential customers and their needs; (b) Strategic marketing is a process of combinations of strengths with potential customer segments; (c) Strategic marketing is a complex marketing, which creates long-time and useful relations between the company and public.

According to (Kotler \& Keller, 2007), strategic marketing ensures optimal value choice with the help of market segmentation, targeting, or positioning.

The fundamental domain of strategic marketing consists in its own precise nature of all corporate questions, decisions and problems touching marketing activities in a company (Varadarajan, 2010). It is necessary to continue assessing individual elements of strategic marketing, especially in the global market, where it is necessary to have an appropriate marketing strategy (Virvilaite et al., 2011; Trudgen \& Freeman, 2014). That explains the importance of corporate performance and relevant impacts of non-financial implications (Milichovsky et al., 2011).

The final output of corporate strategic marketing should include the creation and fixation of actual corporate relations or making stronger relations (Simberova, 2010). These relations provide success of the whole corporate strategy with its performance.

Marketing effectiveness is operationalized as merge of five components designed by Kotler (1977; 1997). These five components are (1) customer philosophy, (2) integrated marketing organization, (3) adequate marketing information, (4) strategic orientation, and (5) operational efficiency.

Appiah-Adu et al., (2001) further argued that first, it is imperative to identify the importance of studying the market, recognizing the numerous opportunities, selecting the most appropriate segments of the market to operate in and endeavoring to offer superior value to meet the selected customer's needs and wants. The firm, they argue, must be suitably staffed to enable it perform marketing analysis, planning and implementation. The company must define its own marketing effectiveness to find its own performance and success.

The article focuses on the importance of marketing effectiveness related to the strategic marketing within the framework of performance measurement and research set through the identification of key metrics. The scientific objective of the paper is to identify a set of metrics which is important from the perspective of marketing strategy and is included in the specific performance group.

Materials and methods: data from primary research and secondary research was used to achieve the previously established objectives. The paper is based on primary research conducted by means of a questionnaire survey, which took place in 2012 in Czech companies. 300 companies were randomly selected to participate in this survey. In total, 115 questionnaires were returned. The output of the primary research was put under statistical processing. The secondary research method consisted in systematic analysis of scientific literature.

Contribution: Two indexes were defined by the said primary research, including key metrics for measuring the marketing effectiveness - (1) profit index, (2) customer index. However, because of the Cronbach alpha indicator, it was only the profit index that reached an acceptable level.

\section{Corporate Performance Systems}

Business performance is becoming an important part of corporate budgeting and performance compensation and promotion (Clark et al., 2006).

The corporate effectiveness depends on the adopted rules of economic efficiency. This concept includes both incurred efficiency of production factors as well as usefulness. From the marketing standpoint, it is important to look at all the actions from the perspective of their impact on the business alone and the corporate performance. Measuring the financial impact of marketing is one of the highest priorities (Williams \& Naumann, 2011; Rutkauskas et al., 2011).

(Lamberti \& Noci, 2010) describe three main specifications of performance systems on which companies have to focus. These specifications are based on the approach how managers reach their goals (checking the strategy implementation; internal communication; validation of fulfilling strategy; improving strategy). These characteristics are:

1. Typology of performance assessed;

2. Typology of measures adopted;

3. Control system of assessing performance.

The key performance indicators (KPI) are a group of metrics that focuses on the most critical areas for current and future development of the company. KPI represents a tool that allows measuring the performance in an appropriate manner to determine right values and then interpret such values correctly. The purpose of KPI lies in the description of the way of increasing performance and improving obtaining results (Parmenter, 2010; Zaherawati et al., 2011; Kerzner, 2011; Hrebicek et al., 2011; Hornungova, 2014).

The KPI system could be crucial for small and medium enterprises (SMEs), which have to focus on results and sustainable development. SMEs use especially financial and accounting indicators along the whole corporate cycle. In addition to financial indicators, it is recommended to use non-financial indicators (Ciemleja \& Lace, 2011).

\section{Marketing Effectiveness}

Marketing effectiveness as concept has been strong associated with many valuable organizational outcome, which should be long-term growth, stable, enhanced customer satisfaction, a competitive advantage and a strong marketing orientation (Webster, 1995, p. 6).

Managers are under pressure. Therefore, they put not only marketing investments under examination. Main results of the examination are reflected in financial 
expressions (e.g., profit, sales or turnover) as the effect of realized marketing activities (Gijsenberg, 2014; Lamberti \& Noci, 2010).

Marketing effectiveness depends on the corporate objectives. Due to the growing demand for marketer's knowledge, it is necessary to focus on the framework where it is possible to measure both short- and long-term financial impacts on enterprise marketing investment. Measuring marketing performance is a business process that provides performance feedback on the results of marketing activities. The effectiveness of marketing activities should be defined as a return of funds invested in these activities. As for the evaluation, there are many various methods how to measure these activities (Farris et al., 2010).

Measuring applies several groups of marketing indicators which help to quantify a possible trend, dynamics or characteristics (Farris et al., 2010). Measuring the performance of marketing activities becomes the business process that provides performance feedback on the results of delivered marketing activities. Business performance becomes an important part of corporate budgeting and performance compensation and promotion (Clark et al., 2006; Ginevicius et al., 2013; Kozena \& Chladek, 2012).

The metric has become a measureable indicator to improve quality level, quantity or financial categories. (Kerzner, 2011) describes the metric as a numerical measur (usually in financial units) representing a part of business data in a specific area. As an indicator, he distinguishes a measure that provides an insight to information requirement and decision making support.

Marketing effectiveness, according to KPI, uses many kinds of metrics, divided into financial and non-financial groups. From the financial point of view, marketing effectiveness could be defined as a return on investment in marketing activities in the company (Milichovsky \& Simberova, 2011; Kocmanova et al., 2010).

There is an affinity between corporate objectives, metrics and a performance system. The metrics and performance system could be taken as subordinate to corporate objectives. In general, metrics is important in project management providing appropriate information. Metrics can be measured and recorded in various ways: in numbers, percentages, counts, or ratings (Kerzner, 2011). Metrics refers to a direct numerical measure in the relationship of one or more dimensions (e.g. gross sales per week). A performance measurement system (PMS) can be defined as the system which managers use in order to (Morgan et al., 2002; Lamberti \& Noci, 2010):

1) check whether the intended strategy is being implemented;

2) communicate to their employees the goals they are expected to achieve and whether they are achieving those expected goals; valid;

3) validate whether the intended strategy is still

4) facilitate individual and organizational learning and improvement.

(Lamberti \& Noci, 2010) designed three main variables for Marketing Performance Measurement System:
(1) Typology of performances assessed specify what are the corporate performances under the responsibility of the marketing units;

(2) Typology of measures adopted;

(3) Control system provides information, how managers assess performances and manage the received information from the MPM system.

Similarly to the analysis of the typology of performances assessed, literature has provided a very heterogeneous set of contributions about the typologies of marketing measures adopted by companies. However, unlike the previous issue, it was possible to detect a widely accepted unifying taxonomy in Clark's theory (Clark, 1999; Lamberti \& Noci, 2010). The author divides marketing measures into four main categories:

- Single financial output measures, representing the first effort to evaluate marketing performances by comparing the outcomes of marketing activities with the costs afforded to implement them;

- Non-financial measures assess outputs through non-financial or qualitative metrics, such as market share, customer satisfaction, or brand equity;

- Input measures target at evaluation of marketing performances by analyzing their resource absorption such marketing budget, or the marketing units' behavior (e.g. marketing audits and controls);

- Multiple measures merge measures for macrodimensions of efficiency, effectiveness and adaptiveness or the interdependency between the different dimensions.

These measures directly depend on the typology of the marketing strategy which each company could use: (1) prospector, (2) defender, and (3) analyser. This typology reflects the corporate position on the market due to an innovative level and using competitive advantages (Valos \& Vocino, 2006).

\section{Marketing Metric}

The marketing metric has become a measurement system, quantifying dynamic and/or static characteristics. In both business and research, marketing metrics include defining objectives, measuring the degree of completion and providing the feedback on processes subject to change. In general, metrics are considered as a standard of measurement and they are used as a corresponding benchmark (Farris et al., 2010; Peters et al., 2013; Ahi \& Searcy, 2015).

The marketing metrics (as a tool how to find effectiveness) could reach the highest level of priority in the whole business environment because of creating a competitive advantage. The reason may include dissatisfaction with the traditional way of measuring marketing activities, associated with accounting, corporate cost-trends, or rapid IT development.

Nowadays, there are a number of different methods that may be used as marketing indicators. These methods help to track business performance through data collection from individual marketing activities, such as marketing campaigns, marketing channels or customer responsiveness (Li, 2011).

The evaluation of impacts of marketing activities is a systematic approach, which begins with the definition of 
the marketing strategy. However, the marketing strategy is usually generally defined owing of the various activities performed. According to the specification of performance systems, the most frequently used marketing metrics may be divided in several groups (see Table 1).

Table 1

Summary of Approaches in Classification of Marketing Metrics

\begin{tabular}{|c|c|c|c|c|}
\hline & & Authors & Description & Examples \\
\hline \multirow{2}{*}{$\begin{array}{l}\text { From the point of } \\
\text { view of results }\end{array}$} & $\begin{array}{l}\text { External market } \\
\text { metrics }\end{array}$ & $\begin{array}{l}\text { Ambler, 2000; Valos \& Vocino, } \\
2006\end{array}$ & $\begin{array}{l}\text { External metrics measures financial changes } \\
\text { of the brand in a short period. }\end{array}$ & $\begin{array}{l}\text { Total number of customers; } \\
\text { Customer satisfaction; } \\
\text { Perceived quality; } \\
\text { Loyalty. }\end{array}$ \\
\hline & $\begin{array}{l}\text { Internal market } \\
\text { metrics }\end{array}$ & $\begin{array}{l}\text { Ambler, 2000; Valos \& Vocino, } \\
2006\end{array}$ & $\begin{array}{l}\text { Internal metrics measures financial changes } \\
\text { of the brand in a short period. }\end{array}$ & $\begin{array}{l}\text { Awareness of goals (vision); } \\
\text { Appetite for learning; } \\
\text { Number of initiatives in } \\
\text { process. }\end{array}$ \\
\hline \multirow{2}{*}{$\begin{array}{l}\text { From the point of } \\
\text { view of financial } \\
\text { expression }\end{array}$} & Financial metrics & $\begin{array}{l}\text { Gaiardelli et al., 2007; Greenyer, } \\
\text { 2006; O'Sullivan et al., 2009; } \\
\text { Lamberti \& Noci, 2010; Valos } \\
\text { \& Vocino, } 2006\end{array}$ & $\begin{array}{l}\text { Financial metrics help to define the accurate } \\
\text { financial amount or use of financial values to } \\
\text { obtain exact values. }\end{array}$ & $\begin{array}{l}\text { Profit; } \\
\text { Turnover; } \\
\text { Marketing expenses; } \\
\text { ROI, ROMI; } \\
\text { EVA. }\end{array}$ \\
\hline & $\begin{array}{l}\text { Non-financial } \\
\text { metrics }\end{array}$ & $\begin{array}{l}\text { Greiling, 2006; Barwise \& } \\
\text { Farley 2004; Zahay \& Griffin, } \\
\text { 2010; Lamberti \& Noci, 2010; } \\
\text { Valos \& Vocino, } 2006\end{array}$ & $\begin{array}{l}\text { Non-financial metrics could not help to } \\
\text { define the exact financial amount. }\end{array}$ & $\begin{array}{l}\text { Customer satisfaction; } \\
\text { Number of visitors; } \\
\text { Loyalty. }\end{array}$ \\
\hline \multirow{2}{*}{$\begin{array}{l}\text { From the point of } \\
\text { view of market } \\
\text { subjects }\end{array}$} & $\begin{array}{l}\text { Customer } \\
\text { metrics }\end{array}$ & $\begin{array}{l}\text { Llonch et al., 2002; Barwise \& } \\
\text { Farley, 2004; Zahay \& Griffin, } \\
2010\end{array}$ & $\begin{array}{l}\text { Customer metrics introduces customer's } \\
\text { movement on the market and their behavior. }\end{array}$ & $\begin{array}{l}\text { Customer lifetime value; } \\
\text { Customer retention; } \\
\text { Share of wallet. }\end{array}$ \\
\hline & Market metrics & $\begin{array}{l}\text { Llonch et al., 2002; Ambler, } \\
2000\end{array}$ & $\begin{array}{l}\text { Market metrics describes the share levels of } \\
\text { individual market activities, competitors or } \\
\text { innovations. }\end{array}$ & $\begin{array}{l}\text { Market share; } \\
\text { Advertising rate; } \\
\text { Losses towards competitors. }\end{array}$ \\
\hline \multirow{2}{*}{$\begin{array}{l}\text { From the point of } \\
\text { view of } \\
\text { performance } \\
\text { results }\end{array}$} & KPI & $\begin{array}{l}\text { Zaherawati et al., 2011; } \\
\text { Parmenter, 2010; Hornungova, } \\
2014\end{array}$ & $\begin{array}{l}\text { It has become a group of metrics, which } \\
\text { shows direction for future increasing of } \\
\text { performance. }\end{array}$ & $\begin{array}{l}\text { Visits to managers next } \\
\text { week; } \\
\text { Customer } \\
\text { ratings; } \\
\text { Net operating margins. }\end{array}$ \\
\hline & KRI & Parmenter, 2010 & $\begin{array}{l}\text { KRI is a group of indicators, which informs } \\
\text { about realized activities. }\end{array}$ & $\begin{array}{l}\text { Net profit before tax; } \\
\text { Return on capital employed; } \\
\text { Profitability per customer. }\end{array}$ \\
\hline \multirow{2}{*}{$\begin{array}{l}\text { From the point of } \\
\text { view of marketing } \\
\text { variables' control }\end{array}$} & $\begin{array}{l}\text { Controllable } \\
\text { variables }\end{array}$ & Sampaio et al., 2011 & $\begin{array}{l}\text { All tools of marketing mix are considered as } \\
\text { controllable variables. }\end{array}$ & $\begin{array}{l}\text { Price; } \\
\text { Product; } \\
\text { Place; } \\
\text { Promotion. }\end{array}$ \\
\hline & $\begin{array}{l}\text { Uncontrollable } \\
\text { variables }\end{array}$ & Sampaio et al., 2011 & $\begin{array}{l}\text { Uncontrollable variables have impacts on } \\
\text { individual marketing decisions and marketing } \\
\text { outputs. }\end{array}$ & $\begin{array}{l}\text { Legal environment; } \\
\text { Economic environment; } \\
\text { Demand fluctuation. }\end{array}$ \\
\hline
\end{tabular}

A number of authors look at marketing metrics from different points of view. Some authors are interested in the financial expression or marketing mix elements, which could be labeled as a traditional classification. Modern classifications may include non-financial metrics which are commonly used in the market area or the customer area. The groups, defined in the Table 1, represent the most frequently used metrics for measuring marketing effectiveness in companies.

\section{Methodology of the Paper}

The main aim of the paper is to define a set of metrics, which is important from the marketing strategic point of view, and is included into the specific performance group.

The first part of the paper presents the key secondary information taken from a number of scientific articles and literature sources. This is followed by the main part of the paper, introducing the selected research data obtained from the primary research.

The conducted primary research was designed on two pillars: (1) the analysis of recent literature sources, (2) internal project at the Faculty of Business and Management, Brno University of Technology, reg. No. FPS-12-1764. This internal project focused on the theoretical analysis of development approaches of marketing and business activities and their effectiveness.

The entire primary research focused on the evaluation of enterprises in the area of business and marketing activities (and their performance) in the Czech Republic. The primary research was conducted in the form of a questionnaire survey. The questionnaire was compiled on the basis of the collected theoretical knowledge, defined areas of issues at hand, and specific objectives so that the 
obtained results may contribute to the setup of KPI for the companies.

For the purpose of this article only one part was selected, targeted on using metrics in the company.

The presented paper is based on the primary research in the form of a questionnaire survey, conducted in 2013 in Czech companies. 300 companies were randomly selected to participate in this survey. In total, 115 questionnaires were returned (relative amount 38,3\%). The largest group of companies which returned the questionnaire belonged to the, manufacturing industry (34\% of companies). The second group was consisted of the business and trade sphere (21\% of companies).

Processing the results of the questionnaire survey made use of both the descriptive statistics and factor analysis. These methods were applied on the selected data set related to measuring the performance of Czech companies.. The data was processed using the statistical software IBM SPSS Statistics 22. The conclusions provide the characteristics of the limitations of our research and its potential further direction.

For the purpose of the article, the data was processed using the factor analysis method. In fact, this method focuses on the multidimensional observations.

The factor analysis is based on the selection of correlation and partial correlation coefficients.

\section{Results}

The discussion and conclusions drawn in this paper are based on the analysis of secondary sources and selected data obtained through a questionnaire survey of marketing management of the Czech companies.

For the purpose of this paper, only selected data, obtained in 2013 and concerning the choice and intensity of the utilization of marketing activities with a view of the company size in the Czech environment, was used (see Table 2).

The results of the questionnaire survey were processed by means of basic types of descriptive statistics analyses using a selected data set. The data was processed using statistical software IBM SPSS Statistics 22.

The research sample consisted of 300 companies randomly selected from the statistical register of business activities - NACE-CZ, and from 115 received questionnaires, 112 of them were fully completed with all the variables. The questionnaires were used for statistical processing. The respondents were managers of the companies under examination who were in charge of marketing and business activities. The respondents to the questionnaire were mainly the owners and managers of engineering companies in the Czech Republic in 2013. The selection criteria included as follows:

1. Geographical location (Czech Republic);

2. The classification of economic activities according to CZ-NACE, limited to the engineering industry.

- 28 - Manufacture of machinery and equipment;

- 29 - Manufacture of motor vehicles, trailers and semi-trailers;

- 30 - Manufacture of other transport equipment.

There are many impacts upon single marketing activities of the company. In the questionnaire, the respondents were asked for marketing metrics which they used in their own corporate measurement.

It is difficult for corporate management to decide which metric is the best for measuring. Therefore, only six metrics were chosen from the questionnaire survey, as shown in Table 3 . The selection was based on the total frequencies.

Table 3 includes rudimentary data displaying that in the performance measurement system, companies use return indicators (ROI and ROMI), customer's indicators (loyalty and customer satisfaction) and costs indicators (EVA and PPC). The conclusions are related to the characteristics of the research limitations and its possible future direction.

The values of the variation coefficient of up to 0,10 indicate low variability; the arithmetic mean may be considered as a typical value of the data file. For this reason, it is appropriate to focus on higher values (see Table 2).

The levels of confidence in Pearson correlation are 99 $\%$ for several relations mentioned in Table 4.

From the values listed in Table 4, it is possible to say that correlations were found only in the case of two metrics that are highlighted. These metrics are Return on Investment $(0,427)$ and Economic Value Added $(0,588)$.

The total variance of the performance indicators is explained by means of eigenvalues, which represent the total variance explained by each factor. The eigenvalues show that only two items reached the minimum value of 1 .

The results of the six-factor model (with all components) show a high and significant loading only in two factors. The observed two factors had eigenvalues higher than 1, explaining $54,98 \%$ of the variance together (see Table 5).

Structure of the Research Sample with a View to Company Size (Number of Employees)

\begin{tabular}{|c|c|c|c|c|c|}
\hline \multicolumn{2}{|r|}{ Company size } & Frequency & Percent & Valid Percent & Cumulative Percent \\
\hline \multirow{6}{*}{ Valid } & No response & 3 & 2,6 & 2,6 & 2,6 \\
\hline & Micro enterprise (1-9) & 26 & 22,6 & 22,6 & 25,2 \\
\hline & Small enterprise (10-50) & 34 & 29,6 & 29,6 & 54,8 \\
\hline & Medium-sized enterprise (51-249) & 42 & 36,5 & 36,5 & 91,3 \\
\hline & Large enterprise (>250) & 10 & 8,7 & 8,7 & 100,0 \\
\hline & Total & 115 & 100,0 & 100,0 & \\
\hline
\end{tabular}


Basic Descriptive Statistics of the Data Under Examination

\begin{tabular}{|l|c|c|c|c|c|c|}
\hline & ROMI & ROI & Loyalty & Customer satisfaction & EVA & Pay per click \\
\hline Mean &, 10 &, 21 &, 16 &, 54 &, 25 &, 11 \\
\hline Std. Deviation &, 298 &, 409 &, 366 &, 501 &, 437 &, 309 \\
\hline Variance &, 089 &, 168 &, 184 &, 251 &, 191 &, 096 \\
\hline Coefficient of variation &, 3356 &, 5134 &, 4372 &, 0778 &, 5721 &, 356 \\
\hline
\end{tabular}

Correlation Matrix of the Chosen Metrics

\begin{tabular}{|c|c|c|c|c|c|c|c|}
\hline & & ROMI & ROI & Loyalty & $\begin{array}{c}\text { Customer } \\
\text { satisfaction }\end{array}$ & EVA & Pay per click \\
\hline ROMI & $\begin{array}{l}\text { Pearson Correlation } \\
\text { Sig. (2-tailed) }\end{array}$ & 1 & $\begin{array}{c}, 427 * * \\
, 000 \\
\end{array}$ & $\begin{array}{l}, 029 \\
, 762 \\
\end{array}$ & $\begin{array}{l}, 010 \\
, 920 \\
\end{array}$ & $\begin{array}{c}365 * * \\
, 000\end{array}$ & $\begin{array}{c}, 274 * * \\
, 003\end{array}$ \\
\hline ROI & $\begin{array}{l}\text { Pearson Correlation } \\
\text { Sig. (2-tailed) }\end{array}$ & $\begin{array}{c}, 427 * * \\
, 000\end{array}$ & 1 & $\begin{array}{l}, 012 \\
, 896 \\
\end{array}$ & $\begin{array}{r}-, 079 \\
, 401 \\
\end{array}$ & $\begin{array}{c}588 * * \\
, 000\end{array}$ & $\begin{array}{l}, 111 \\
, 241 \\
\end{array}$ \\
\hline Loyalty & $\begin{array}{l}\text { Pearson Correlation } \\
\text { Sig. (2-tailed) }\end{array}$ & $\begin{array}{l}, 029 \\
, 762\end{array}$ & $\begin{array}{l}, 012 \\
, 896\end{array}$ & 1 & $\begin{array}{c}, 259 * * \\
, 005\end{array}$ & $\begin{array}{c}-, 032 \\
, 736\end{array}$ & $\begin{array}{l}, 096 \\
, 312\end{array}$ \\
\hline $\begin{array}{l}\text { Customer } \\
\text { satisfaction }\end{array}$ & $\begin{array}{l}\text { Pearson Correlation } \\
\text { Sig. (2-tailed) }\end{array}$ & $\begin{array}{l}, 010 \\
, 920 \\
\end{array}$ & $\begin{array}{r}-, 079 \\
, 401 \\
\end{array}$ & $\begin{array}{c}, 259 * * \\
, 005\end{array}$ & 1 & $\begin{array}{l}-, 061 \\
, 517 \\
\end{array}$ & $\begin{array}{r}-, 021 \\
, 822 \\
\end{array}$ \\
\hline EVA & $\begin{array}{l}\text { Pearson Correlation } \\
\text { Sig. (2-tailed) }\end{array}$ & $\begin{array}{c}, 365^{* * *} \\
.000\end{array}$ & $\begin{array}{c}, 588 * * \\
, 000\end{array}$ & $\begin{array}{c}-, 032 \\
, 736 \\
\end{array}$ & $\begin{array}{r}-, 061 \\
, 517\end{array}$ & 1 & $\begin{array}{l}, 135 \\
, 154\end{array}$ \\
\hline Pay per click & $\begin{array}{l}\text { Pearson Correlation } \\
\text { Sig. (2-tailed) }\end{array}$ & $\begin{array}{c}, 274 * * \\
, 003\end{array}$ & $\begin{array}{l}111 \\
, 241\end{array}$ & $\begin{array}{l}, 096 \\
, 312\end{array}$ & $\begin{array}{l}-, 021 \\
, 822\end{array}$ & $\begin{array}{l}, 135 \\
, 154\end{array}$ & 1 \\
\hline
\end{tabular}

**. Correlation is significant at the 0.01 level (2-tailed).

Table 5

Total variance of Chosen Metrics

\begin{tabular}{|c|c|c|c|c|c|c|c|c|c|}
\hline \multirow{2}{*}{ Component } & \multicolumn{3}{|c|}{ Initial Eigenvalues } & \multicolumn{3}{|c|}{ Extraction Sums of Squared Loadings } & \multicolumn{3}{|c|}{ Rotation Sums of Squared Loadings } \\
\hline & Total & $\%$ of Variance & Cumulative \% & Total & $\%$ of Variance & Cumulative \% & Total & $\%$ of Variance & Cumulative $\%$ \\
\hline 1 & 2,015 & 33,580 & 33,580 & 2,015 & 33,580 & 33,580 & 2,007 & 33,450 & 33,450 \\
\hline 2 & 1,284 & 21,400 & 54,980 & 1,284 & 21,400 & 54,980 & 1,292 & 21,530 & 54,980 \\
\hline 3 & ,951 & 15,854 & 70,834 & & & & & & \\
\hline 4 & ,743 & 12,386 & 83,220 & & & & & & \\
\hline 5 &, 597 & 9,950 & 93,170 & & & & & & \\
\hline 6 & 410 & 6,830 & 100,000 & & & & & & \\
\hline
\end{tabular}

Extraction Method: Principal Component Analysis.

Table 6 These two groups define two synthetic dimensions of the view on measuring performance with an impact on managerial decision-making.

In order to assess whether it is possible to use the factor analysis, Kaiser-Meyer-Olkin method (KMO) and Bartlett's test of sphericity were used. The KMO method is based on selective correlation and partial correlation coefficients.

\section{Discussion}

The KMO value range is between 0 and 1 . Each variable correlates perfectly to itself (approximate to 1), but has no correlation to the other variables (approximate to 0 ). In our case, the KMO reached value of 0.6 , which means that the performed level of usefulness of the factor analysis has an average value.

Bartlett's test of sphericity is a statistic test used to examine the hypothesis that the variables are correlated or uncorrelated. According to the KMO, no correlation was found with other variables $(\mathrm{Sig}=0)$.

According to our results, the values of Cronbach's alpha were on an acceptable level for the Profit group, and on nearly a good level for the group of Value added.

The profit factor (as a group) could be put into the financial group and KRI, because individual indicators show results of realized activities (according to Table 1). 
A similar approach is used for the above-mentioned Customer Factor. The indicators in this factor should be included in the Non-financial group, Customer group and External group (according to Table 1).

According to our results, the values of Cronbach's alpha were:

- The Profit Factor is at a good level;

- The Customer Factor is unacceptable.

Chosen Profit factor includes key indicators which companies could use to find own marketing effectiveness.

\section{Conclusions}

The correct choice of performance indicators is an important part of the corporate strategic process. The definition of performance indicators is quite difficult because of the complexity of measureable areas.

A strategic plan defines a basis for effective measurement in the performance system. For the purposes of proper measurement, it is essential to focus on appropriate factors and indicators.

It is possible to derive quality information and availability of the existing elements from the strategic plan measurement. To achieve the goal of finding the accurate elements, it is necessary to find regular answers on five areas:

- Choice of information to publication,

- Liability for collecting information,

- Way and period of publication measurement,

- Way of publication information,

- For who is measurement dedicated.

The information obtained on mentioned fields is a fundament for achieving the required performance and effectiveness - not only marketing activities, but in the whole company.
(Zahay \& Griffin, 2010) perceive as the main problem that companies do not measure performance on the customer level. It may have an implication on misunderstanding the results for marketers. The measurement of customer performance usually depends on fields of corporate activities, if the company operates in the industry market or in the services market.

The objective of each company should consist in dividing all customers only into two higher levels (partner and advocate) because they create the highest value for the company. These customers are automatically taken as satisfied customers (Simberova, 2008).

Strategic marketing is one of the most important parts of complex corporate strategies on which each company has to focus. For the purposes of measuring the marketing effectiveness, it is necessary to focus on customers, and the potential behavior trend of a selected market segment. For this reason, it is important to choose the appropriate metric corresponding to the current market position and creating favorable marketing background for potential expansion.

Our research showed that there is a large space for improvement. This improvement will offer new opportunities to companies to increase their competitiveness in corporate management in the Czech environment.

According to the results of the factor analysis and Cronbach's alpha measure, it is recommended to use only the profit factor, which engineering companies should apply when measuring marketing effectiveness. It is thus becoming the primary factor.

The limitation of this paper consists in its focus on domestic companies. Therefore, further research should make use of the knowledge not only of the domestic environment, but also the international environment to ascertain the influence of the corporate performance measurement system.

\section{References}

Ahi, P., \& Searcy, C. (2015). An analysis of metrics used to measure performance in green and sustainable supply chain. Journal of Cleaner Production, 86(1), 360-377. http://dx.doi.org/10.1016/j.jclepro.2014.08.005

Ambler, T. (2000). Marketing metrics. Business Strategy Review, 11(2), 59-66. http://dx.doi.org/10.1111/1467-8616. 00138

Appiah-Adu, K., Fyall, A., \& Singh, S. (2001). Marketing effectiveness and business performance in the financial services industry. Journal of Services Marketing, 15(1), 18-32. http://dx.doi.org/10.1108/08876040110381346

Baker, S., \& Holt, S. (2004). Making marketers accountable: a failure of marketing education? Marketing Intelligence \& Planning, 22(5), 557-567. http://dx.doi.org/10.1108/02634500410551932

Barwise, P., \& Farley, J. U. (2004). Marketing metrics: Status of six metrics in five countries. European Management Journal, 22(3), 257-262. http://dx.doi.org/10.1016/j.emj.2004.04.012

Ciemleja, G., \& Lace, N. (2011). The Model of Sustainable Performance of Small and Medium-sized Enterprise. Inzinerine Ekonomika-Engineering Economics, 22(5), 501-509. http://dx.doi.org/10.5755/j01.ee.22.5.968

Clark, B. H. (1999). Marketing performance measures: History and interrelationships. Journal of Marketing Management, 15, 711-732. http://dx.doi.org/10.1362/026725799784772594

Clark, B. H., Abela, A. V., \& Ambler, T. (2006). An information processing model of marketing performance measurement. Journal of Marketing Theory and Practice, 14(3), 191-208. http://dx.doi.org/10.2753/MTP1069-667 9140302

DeVellis, R. F. (2003). Scale Development: Theory and Application. Sage Publications, London.

Doyle, P. (2008). Value-based marketing. Chichester: John Wiley \& Sons. 380 p.

Farris, P. W., Bendle, N. T., Pfeifer, P. E., \& Reibstei, D. J. (2010). Marketing metrics: The Definitive guide to measuring marketing performance. 2.ed. New Jersey: Pearson Education, p. 414. 
Gaiardelli, P., Saccani, N., \& Songini, L. (2007). Performance Measurement of the After-sales Service Network Evidence from the Automotive Industry. Computers in Industry, 58(7), 698-708. http://dx.doi.org/10. 1016/j.compind.2007.05.008

Gijsnberg, M. J. (2014). Comment: Measuring marketing effectiveness around major sports events: A comparison of two studies and a call for action. International Journal of Research in Marketing, 31(1), 30-32. http://dx.doi.org/10. 1016/j.ijresmar.2014.02.001

Ginevicius, R., Podvezko, V., \& Ginevicious, A. (2013). Quantitative evaluation of enterprise marketing activities. Journal of Business Economics and Management, 14(1), 200-212. http://dx.doi.org/10.3846/16111699.2012.731143

Gok, O., \& Hacioglu, G. (2010). The organizational roles of marketing and marketing managers. Marketing Intelligence \& Planning, 28(3), 291-309. http://dx.doi.org/10.1108/02634501011041435

Greenyer, A. (2006). Measurable marketing: A Review of development in marketing's measurability. Journal of Business \& Industrial Marketing, 21(4), 239-242. http://dx.doi.org/10.1108/08858620610672605

Greiling, D. (2006). Performance measurement: A remedy for Increasing the Efficiency of Public Services? International Journal of Productivity and Performance Management, 55(6), 448-465. http://dx.doi.org/10.1108/17410400610 682488

Gronholdt, L., \& Martensen, A. (2006). Key marketing performance measures. The Marketing Review, 6(6), $243-52$.

Hornungova, J. (2014). Factor Analysis: An Instrument for Selection of Social Performance Factors. Revista de Metodos Cuantitativos para la Economia y la Empresa, 17(6), 121-136. http://dx.doi.org/10.1362/146934706778605287

Hrebicek, J., Soukopova, J., Stencl, M., \& Trenz, O. (2011). Integration of economic, environmental, social and corporate governance performance and reporting in enterprises. Acta Universitatis Agriculturae et Silviculturae Mendelianae Brunensis, 59(7), 157-166. http://dx.doi.org/10.11118/actaun201159070157

Jakubikova, D. (2008). Strategicky marketing: Strategie a trendy. Praha: Grada Publishing. 269.

Kahn, K. B., \& Myers, M. B. (2005). Framing marketing effectiveness as a process and outcome. Marketing Theory, 5(4), 457-469. http://dx.doi.org/10.1177/1470593105058825

Kerzner, H. (2011). Project Management Metrics, KPIs and Dashboards: A Guide to measuring and monitoring project performance. New Jersey: John Wiley \& Sons. 372. http://dx.doi.org/10.1002/9781118086254

Kocmanova, A., Hornungova, J., \& Klimkova, M. (2010). Udrzitelnost: Integrace environmentalni, socialni a ekonomicke vykonnosti podniku. Brno: Akademicke nakladatelstvi CERM, 125.

Kocmanova, A., \& Simberova, I. (2012). Modelling of Corporate Governance Performance Indicators. Inzinerine Ekonomika-Engineering Economics, 23(5), 485-495.

Kotler, P. (1977). From sales obsession to marketing effectiveness. Harvard Business Review, 55, 67-75.

Kotler, P. (1997). Marketing Management, Analysis Planning, Implementation and Control, New Jersey: Prentice-Hall.

Kotler, P., \& Keller, K. L. (2007). Marketing Management. Praha: Grada Publishing. 788.

Kozena, M., Chladek, T. (2012). Company Competitiveness Measurement Depending on its Size and Field of Activities. Procedia - Social and Behavioral Sciences, 58(12), 1085-1090. http://dx.doi.org/10.1016/j.sbspro.2012.09.1089

Lamberti, L., \& Noci, G. (2010). Marketing strategy and marketing performance measurement system: Exploring the relationship. European Management Journal, 28(2), 139-152. http://dx.doi.org/10.1016/j.emj.2009.04.007

Lehmann, D. R. (2004). Metrics for making marketing matter. Journal of Marketing, 68(4), 73-75.

Li, L. Y. (2011). Marketing metrics' usage: Its predictors and implications for customer relationship management. Industrial Marketing Management, 40(1), 139-148. http://dx.doi.org/10.1509/jmkg.68.4.73.42727

Llonch, J., Eusebio, R., \& Ambler, T. (2002). Measures of marketing success: A Comparison between Spain and the UK. European Management Journal, 20(4), 414-422. http://dx.doi.org/10.1016/S0263-2373(02)00064-6

Milichovsky, F., Solcansky, M., \& Sychrova, L. (2011). Pristupy k mereni efektivnosti marketingovych cinnosti. Trendy ekonomiky a managementu. 5(8), 131-138.

Milichovsky, F., \& Simberova, I. (2011). Signification of marketing effectiveness in industry. In International Scientific Conference Whither Our Economies, 1(1), 98-103.

Morgan, N. A., Clark, B. H., \& Gooner, R. (2002). Marketing productivity, marketing audits, and systems for marketing performance assessment: Integrating multiple perspectives. Journal of Business Research, 55(5), 363-375. http://dx.doi.org/10.1016/S0148-2963(00)00162-4

Neil, S., McKee. D., \& Rose, G. (2007). Developing the organization's sense making capability: Precursor to an adaptive strategic marketing response. Industrial Marketing Management, 36(6), 731-744. http://dx.doi.org/10.1016/ j.indmarman.2006.05.008

O’Sullivan, D., Abela, A. V., \& Hutchinson, M. (2009). Marketing performance measurement and firm performance: Evidence from the European high-technology sector. European Journal of Marketing, 43(5/6), 843-862. http://dx.doi.org/10. 1108/03090560910947070 
Parmenter, D. (2010). Key performance indicator: Developing, implementing and using winning KPIs. New Jersey: John Wiley \& sons, 299.

Peters, K., Chen, Y., Kaplan, A. M., Ognibeni, B., \& Pauwels, K. (2013). Social media metrics - A framework and guidelines for managing social media. Journal of Interactive Marketing, 27(4), 281-298. http://dx.doi.org/10. 1016/j.intmar.2013.09.007

Rust, R. T., Ambler, T., Carpenter, G. S., Kumar, V., \& Srivastava, R. K. (2004). Measuring marketing productivity: current knowledge and future directions. Journal of Marketing, 68(3), 76-89. http://dx.doi.org/10.1509/jmkg.68.4. 76.42721

Rutkauskas, A. V., Lapinskaite-Vvohlfahrt, I., \& Stasytyte, V. (2011). Marketing Portfolio Management in a Spectrum of Marketing Assets Interaction to Maximize Holder's Utility. Inzinerine Ekonomika-Engineering Economics, 22(5), 485-493. http://dx.doi.org/10.5755/j01.ee.22.5.967

Sampaio, C. H., Simoes, C., Perin, M. G., \& Almeida, A. (2011). Marketing metrics: Insights from Brazilian managers. Industrial Marketing Management, 40(1), 8-16. http://dx.doi.org/10.1016/j.indmarman.2010.09.005

Sevin, C. H. (1965). Marketing productivity analysis. McGraw-Hill, New York City, NY.

Sheth, J. N., \& Sisodia, R. S. (2002). Marketing productivity: issues and analysis. Journal of Business Research, 55(5), 349-62. http://dx.doi.org/10.1016/S0148-2963(00)00164-8

Stewart, D. W. (2009). Marketing accountability: linking marketing actions to financial results. Journal of Business Research, 62(6), 636-43. http://dx.doi.org/10.1016/j.jbusres.2008.02.005

Simberova, I. (2010). Company strategic marketing management - synergic approach and value creating. Acta univ. agric. et silvic. Mendel. Brun., 58(6), 543-552. http://dx.doi.org/10.11118/actaun201058060543

Simberova, I. (2008). Vztahy se stakeholdery v soudobych marketingovych koncepcich. Trendy ekonomiky a managementu, 2(2), 71-80.

Tikkanen, H., Kujala, J., \& Artto, K. (2007). The marketing strategy of a project-based firm: The four portfolio framework. Industrial Marketing Management, 36(2), 194-205. http://dx.doi.org/10.1016/j.indmarman.2006.03.006

Trudgen, R., \& Freeman, S. (2014). Measuring the performance of born-global firms throughout their development process: The roles of initial market selection and internationalization speed. Management International Review, 54(4), 551-579. http://dx.doi.org/10.1007/s11575-014-0210-y

Valos, M. J., \& Vocino, A. (2006). An integrative marketing channel performance measurement framework. Journal of Database Marketing \& Customer Strategy Management, 14(1), 17-28. http://dx.doi.org/10.1057/palgrave. dbm.3250037

Varadarajan, R. (2010). Strategic marketing and marketing strategy: domain, definitive, fundamental issues and foundational premises. Journal of the Academic Marketing Science, 38, 119-140. http://dx.doi.org/10.1007/s11747009-0176-7

Virvilaite, R., Seinauskiene, B., \& Sestokiene, G. (2011). The link between standardization/adaptation of international marketing strategy and company performance. Inzinerine Ekonomika-Engineering Economics, 22(1), $106-117$. http://dx.doi.org/10.5755/j01.ee.22.1.223

Webster, C. (1995). Marketing culture and marketing effectiveness in service firms. Journal of Services Marketing, 9(2), 6-21. http://dx.doi.org/10.1108/08876049510085973

Webster, F. E. Jr, Malter, A. J., \& Ganesan, S. (2005). The decline and dispersion of marketing competence. MIT Sloan Management Review, 46(4), 35-43.

Williams, P., \& Naumann, E. (2011). Customer Satisfaction and Business Performance: a Firm-level Analysis. Journal of Service Marketing, 25(1), 20-32. http://dx.doi.org/10.1108/08876041111107032

Zahay, D., \& Griffin, A. (2010). Marketing strategy selection, marketing metrics and firm performance. Journal of Business \& Industrial Marketing, 25(2), 84-93. http://dx.doi.org/10.1108/08858621011017714

Zaherawati, Z., Z, Mahazril, A. Y., Zuraini, Y., Nazni, N., Mohd Zool Hilmie, M. S., \& Zuriawati, Z. (2011). Key Performance Indicators (KPIs) in the Public Sector: A Study in Malaysia. Asian Social Science. 7(7), 102-107.

The article has been reviewed.

Received in March, 2013; accepted in April, 2015. 